\title{
HIV-1 co-receptor usage:influence on mother- to-child transmission and pediatric infection
}

\author{
Mariangela Cavarelli, Gabriella Scarlatti
}

\begin{abstract}
Viral CCR5 usage is not a predictive marker of mother to child transmission (MTCT) of HIV-1. CXCR4-using viral variants are little represented in pregnant women, have an increased although not significant risk of transmission and can be eventually also detected in the neonates. Genetic polymorphisms are more frequently of relevance in the child than in the mother. However, specific tissues as the placenta or the intestine, which are involved in the prevalent routes of infection in MTCT, may play an important role of selective barriers.

The virus phenotype of the infected children, like that of adults, can evolve from R5 to CXCR4-using phenotype or remain R5 despite clinical progression to overt immune deficiency. The refined classification of R5 viruses into R5 $5^{\text {narrow }}$ and R5 $5^{\text {broad }}$ resolves the enigma of the R5 phenotype being associated with the state of immune deficiency. Studies are needed to address more in specific the relevance of these factors in HIV-1 MTCT and pediatric infection of non-B subtypes.
\end{abstract}

\section{Maternal viral co-receptor usage is not prognostic of transmission}

The comparison of the co-receptor usage of viral variants obtained from transmitting and non-transmitting HIV-1 infected mothers demonstrated that most maternal viral isolates used CCR5 to infect target cells, alone or in association with other co-receptors, thus indicating that CCR5 usage is not a predictive marker of mother to child transmission (MTCT) of HIV-1 [1-4].

The high proportion of women carrying R5 virus prompted us to investigate if the intrinsic variability of these viruses may contribute to identifying a correlate of protection of MTCT. We made use of the newly introduced and refined R5 viral characterization, in which viruses are further classified in $\mathrm{R} 5^{\text {broad }}$ or $\mathrm{R} 5^{\text {narrow }}$ according to their capacity to use or not CCR5/CXCR4 chimeric receptors besides the wild-type CCR5 [5]. In particular, it was shown that during disease progression of infected adults R5 viruses evolved to multiple chimeric receptor usage, which in turn correlated with the $\mathrm{CD} 4+\mathrm{T}$ cell decline in the patient. The use of chimeric receptors was interpreted as the evolution to an extended flexibility in the use of the CCR5, as R $5^{\text {broad }}$

\footnotetext{
* Correspondence: scarlatti.gabriella@hsr.it

Unit of Viral Evolution and Transmission, Division of Immunology, Transplant and Infectious Diseases, San Raffaele Scientific Institute, Via Olgettina 58, 20132 Milan, Italy
}

(c) 2010 Cavarelli and Scarlatti; licensee BioMed Central Ltd. This is an open access article distributed under the terms of the Creative Commons Attribution License (http://creativecommons.org/licenses/by/2.0), which permits unrestricted use, distribution, and reproduction in any medium, provided the original work is properly cited. viruses have higher infectivity with the wild-type CCR5 than isolates with the $R 5^{\text {narrow }}$ phenotype.

Against our expectations we showed that mothers harbouring $R 5^{\text {broad }}$ viruses were not at a higher risk of transmission than those with $R 5^{\text {narrow }}$ viruses [6], thus again supporting that the R5 phenotype is not predictive of transmission. However, the maternal viral phenotype (either $\mathrm{R} 5^{\text {narrow }}$ or $\mathrm{R} 5^{\text {broad }}$ ) was generally preserved during transmission and predictive of the phenotype of the viral variant transmitted to the newborn.

Our original studies showed that the syncytium-inducing (SI), CXCR4-using viral variants were involved in MTCT of HIV-1 [4,7]. Indeed, HIV-1 infected mothers who harbor virus able to replicate in cell lines (rapid/ high virus) and form syncytia in MT-2 cells had a higher although not significant risk of transmission than mothers with slow/low and non-SI viruses $[4,7]$. The number of mothers analyzed is however limited, and focused on subtype B HIV-1 infections.

A limited number of studies analyzed the role of the viral phenotype in MTCT within non-B HIV-1 subtypes. Indeed, subtype $C$ followed by $A, D, G$ and some circulating recombinant forms of HIV-1 are predominant in the world and specially in high endemic areas [8]. In pregnant women the major co-receptor for HIV-1 remains CCR5 also for viruses of subtypes A, C and G $[9,10]$. In addition isolates of these latter subtypes used 
frequently alternative chemokine receptors as for examples CXCR6 or CCR1, and rarely CXCR4 $[1,11]$. If these alternative chemokine receptor have a relevance is not yet clarified. It is of interest that CXCR6 is expressed on trophoblasts and may thus play a role for in utero transmission [12]. Further studies are needed to address if co-receptors others than CCR5 may have any relevance in HIV-1 MTCT of non-B subtypes.

\section{Selection or no selection: which virus is transmitted?}

The very first studies comparing the genetic sequence of viruses from mother and child showed that the maternal viral population is more heterogeneous than that of the child [7,13-15]. If only a limited number of variants are originally transmitted and/or are initially replicating in the child is still a matter of discussion. On the one hand it was shown that a minor viral variant of the mother constituted the dominant variant in the child, on the other also a major maternal variant could be detected in the child $[7,13,16-18]$. If selective infection occurs, one could argue that an association between viral phenotype and transmission exist, however, all viral phenotypes, though to a different proportion, were detected in vertically infected children. On the other hand it was shown that selection may occur in relation to the different transmission routes, in utero vs. intra partum. Indeed, a major maternal virus variant as well as subtype $C$ variants compared to A and D are associated with in utero transmission $[14,15,19]$.

Indeed, R5 isolates are preferentially isolated from offspring [3,7,20-22], however, this could be a direct consequence of the higher frequency of mothers carrying R5 compared to X4 viruses. A more sophisticated analysis of the mother's R5 viruses and of their child allowed us to pinpoint that the phenotype, either $R 5^{\text {narrow }}$ or $\mathrm{R} 5{ }^{\text {broad }}$, was usually maintained during the transmission event [6]. These data lend support to the lack of restriction in transmission of $\mathrm{R} 5^{\text {broad }}$ viruses and favor the possibility that the maternal viral R5 phenotype is predictive of the transmitted variant.

On the contrary, the maternal R5X4 phenotype can be lost during transmission [6]. Mothers with an R5X4 virus transmitted virus with a whole array of phenotypes, i.e. $\mathrm{R} 5^{\text {narrow }}, \mathrm{R} 5^{\text {broad }}$ or R5X4. A definitive explanation for the inefficient transmission of $\mathrm{X} 4$ variants was not cleared yet. One possibility is that $\mathrm{X} 4$ variants are transmitted but rapidly deleted in the offspring, or that susceptibility of the child's cells to infection by the mother's isolate favors R5 variants, as discussed below. It is important to notice, that CXCR4 using variants were isolated from the children when the mother also carried such phenotype at delivery, indicating that transmission of $\mathrm{X} 4$ variants can occur with appropriate conditions. A recent study supports these data in non-B subtype virus infection [23]. Here the Authors demonstrate that in five Ugandan mother-child pairs X4 and R5X4 viruses are transmitted before, during or shortly after delivery, and thus, establish vertical transmission as an important source of CXCR4-using viruses in infants.

Another interesting observation comes from the study by Casper et al. [1], which shows that in HIV-1 infected children the emergence of the $\mathrm{X} 4$ phenotype during disease progression occurs when the mother carried an X4 virus. The same group was able to demonstrate that in these two children the $\mathrm{X} 4$ virus developed from their own R5 population, and not from a transmitted maternal X4 variant [24]. It is tempting to speculate that the transmitted virus has an intrinsic propensity to evolve to CXCR4 usage or that the similar genetic background of the mother and the child may favor such evolution.

\section{Viral phenotype correlates with pediatric disease progression}

Children with perinatally acquired HIV-1 infection exhibit a widely variable clinical outcome: approximately one-forth of infants become symptomatic and develop AIDS within the first months of life, whereas the others remain asymptomatic or have only mild symptoms for several years $[25,26]$. A whole array of parameters, like the gestational period in which fetal infection occurs, and the child's or the mother's immunocompetent status, may influence infection outcome, and one of the crucial viral factors besides the viral load is the biological phenotype.

The virus phenotype of the infected children, like that of adults, can evolve from R5 to CXCR4-using phenotype or remain $\mathrm{R} 5$ despite clinical progression to overt immune deficiency [1,27-32]. Children progressing rapidly within a few years of age to disease may harbor R5 viruses but possibly have an elevated and fast increasing viral and proviral load associated $[20,32]$.

$\mathrm{X} 4$ viruses are rarely isolated from neonates, and their predictive value of a rapid AIDS outcome showed discordant results [28,29,32-34]. Most of these reports unfortunately analyzed a limited number of children as to provide conclusive answers. Kopka et al. characterized 62 viral isolates of a cohort with an unusual high percentage (18\%) of SI variants within the first 5 months of age, and showed that the presence of HIV-1 variants with rapid replication capability and/or an SI phenotype is indicative of a poor prognosis favoring CD4+ T cell depletion and rapid progression to AIDS [35]. On the contrary, in another study accurate sampling throughout the disease showed that CXCR4-using viruses possibly emerge in some children as a consequence of the severe immune deficiency [1]. In a recent study of a large cohort of 126 children and adolescent, included in the 
Hemophilia Growth and Development Study cohort, the baseline CXCR4 usage of their isolates predicted progression to clinical AIDS [36]. It can be argued that the two transmission routes, from the mother or through blood products, has different outcomes. However, if it is now well established knowledge that the CXCR4-using phenotype is associated with a severe state of immune deficiency, its predictive value is still controversial.

Increasing evidences are emerging showing that the classical dichotomy of the viral phenotype into R5 and $\mathrm{X} 4$ is not sufficient to explain the large phenotypic variation of HIV-1 [5]. Further classification of R5 viruses into $\mathrm{R} 5^{\text {narrow }}$ and $\mathrm{R} 5^{\text {broad }}$ permitted to explain why some children progress more rapidly than others, despite the early presence of an R5 phenotype close to birth [6]. Our recent study performed on 28 infected newborns demonstrated that the presence of viruses with $\mathrm{R} 5^{\text {broad }}$ phenotype close to birth was significantly associated with a fast progression to severe immunological failure within 3 years of age (Figure 1). Thus, infection in children established by $R 5^{\text {broad }}$ viral variants with an envelope conformation that allows for a more efficient CCR5 use, determine detrimental effects similar to those known for CXCR4 using viruses. The refined classification of $\mathrm{R} 5$ viruses into $\mathrm{R} 5^{\text {narrow }}$ and $\mathrm{R} 5^{\text {broad }}$ resolves the enigma of the R5 phenotype being associated with the state of immune deficiency. These data support the finding by Casper et al. [1], who suggested that the immunological deterioration in HIV-1 infected children precedes the viral phenotypic switch to CXCR4 usage. One could argue that pre-existing $\mathrm{R} 5^{\text {broad }}$ viruses may have caused the worsening of the disease in the cohort analyzed by this study.

We documented also the phenotypic evolution from a wild-type $\mathrm{R} 5$ to broad chimeric receptor using viruses of HIV-1 infected children during disease progression [37] (and unpublished results), which is paralleled by an increase of CCL5/RANTES resistance of the virus in vitro. Our hypothesis is that virus variants may evolve towards a more efficient CCR5 usage and improved binding properties, possibly due to selection pressure exerted by the presence of chemokines abundant in HIV-1 infected persons [38,39]. Accordingly, R $5^{\text {broad }}$ viruses may be considered escape variants as much as CXCR4 using viruses. It is desirable that this different sensitivity of $\mathrm{R} 5^{\text {broad }}$ viruses to CCR5 ligands is further

\section{CDC3 stage at age \\ Viral phenotype at birth \\ FAST PROGRESSOR \\ $<12$ months \\ R5narrow ( $n=5)$ \\ R5broad ( $n=4)$ \\ 13 to 36 months

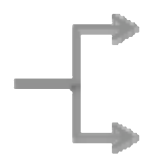 \\ R5narrow (n=4) \\ R5broad ( $n=2)$ \\ SLOW PROGRESSOR 36 to 60 months $\longrightarrow$ R5narrow (n=5) \\ 60 to 96 months $\longrightarrow$ R5narrow (n=5) \\ Figure 1 The $\mathbf{R} 5^{\text {broad }}$ phenotype is predictive of early immunological failure in children. Categories are defined according to the Centers for Disease Controls [111]: CDC 3 = severe immune suppression. Narrow and broad refer to viruses with R5 phenotype detected at or close to birth. Viruses able to exclusively use wild type CCR5 receptor are defined narrow, whereas those using chimeric receptors besides the wild type CCR5 are defined broad. Statistical analysis was performed to detect the influence of the virus with R5broad phenotype on disease progression of the children; $\mathrm{p}=0.0218$ (Pearson's chi Square).}


investigated since clinical trials introducing small CCR5 inhibitors for the treatment of pediatric HIV-1 infections are forthcoming.

\section{Relevance of co-receptor expression on HIV-1 cell targets}

Since R5 viruses are predominant in MTCT of HIV-1, the interaction of $\mathrm{R} 5$ viruses with $\mathrm{CD} 4+\mathrm{CCR} 5+\mathrm{T}$ cells may play an important role in the pathogenesis of pediatric AIDS. In neonates the memory CD4+ T cells (CD45RO+), which express high levels of CCR5, are 6 to 7 times less represented than the naïve CD4+ cells (CD45RA) [40]. The latter predominantly express CXCR4 [40-43] and were shown to be primarily infected by CXCR4 using viruses [44]. The paucity of memory CD4+ T cells in cord blood imply that CCR5positive cells are relatively uncommon [42]. However, at later age, in infants and children, the majority of the HIV-1-infected CD4 $+\mathrm{T}$ cells in the blood display a memory $(\mathrm{CD} 45 \mathrm{RO}+)$ phenotype [43]. The more efficient use of the wild-type CCR 5 by $5^{\text {broad }}$ compared to $\mathrm{R} 5^{\text {narrow }}$ viruses $[5,37]$ supports the hypothesis that the $R 5^{\text {broad }}$ viruses may infect, in addition to memory cells, also CD4+ naïve cells despite the limited expression of the CCR5 molecule on their surface. Interestingly, although HIV-1 infected neonates in general had 10 to 100 fold higher number of infected CD4+ memory than naïve cells, those children who rapidly progressed towards disease had high proviral load in the CD4+ naïve cells $[43,45]$. It remains to be solved why CXCR4 using viruses are not maintained during transmission, despite the high prevalence of CXCR4+ naïve cells in neonates.

Besides CD4+ T lymphocytes HIV-1 infects also other cells of the immune systems, like macrophages and dendritic cells (DCs). The infection of monocytes/ macrophages is of major importance since these cells act as reservoir of the virus. Cord blood derived monocyte/macrophages have an increased susceptibility to HIV-1 infection in vitro with $\mathrm{R} 5$ but not $\mathrm{X} 4$ virus compared to adult cells [46]. DCs, which are also abundant at mucosal sites, may have a relevant role being the intestine the preferential route of MTCT of HIV-1. Immature DCs do not express CXCR4 and allow infection through a CCR5-mediated process (cis infection), which would be in favor of a preferential R5 infection. However, DCs support transfer of virus, independent of co-receptor usage, via DC-SIGN (trans infection) [47].

All these studies underline the relevance of the expression of the different receptors for HIV-1 in cells derived from the peripheral blood, but little is known on cellular HIV targets in relevant tissues, as for example the gut or the placenta, of newborns and children (see chapter below).

\section{Genetic polymorphisms: determinants of expression of relevant receptors}

Polymorphisms implicated in MTCT and pediatric disease progression are summarized in Table 1.

Particularly interesting is a 32-nucleotide deletion $(\Delta 32)$ of the CCR5 gene that renders the co-receptor non functional when homozygote or expressed to lower levels when heterozygote [48-51]. The incidence of the $\triangle 32$ CCR5 allele is high in Caucasian population, approximate $1 \%$ are homozygous and $20 \%$ heterozygous, but appears only sporadically in Asian and African populations [52]. A study on MTCT, described that the homozygous mutation confers resistance to infection [53]. However, in adults despite this genotype the protection is not absolute and some rare cases of HIV-1 infection were reported possibly due to transmission of CXCR4-using viruses. In MTCT there are no studies

Table 1 Effect of genetic polymorphisms of HIV-1 receptors and ligands on HIV-1 mother-to-child transmission and pediatric disease progression

\begin{tabular}{|c|c|c|c|c|}
\hline \multirow[t]{2}{*}{ Gene } & \multirow[t]{2}{*}{ Polymorphism } & \multicolumn{2}{|l|}{ Influence on } & \multirow[t]{2}{*}{ Ref. } \\
\hline & & MTCT risk & $\begin{array}{c}\text { Disease } \\
\text { progression }\end{array}$ & \\
\hline CCR5 & delta32 & Decreased & Delayed & 53,63 \\
\hline CCR5 & $59029 \mathrm{~A}$ & Augmented & Accelerated & 62 \\
\hline CCR2 & 641 & Contradicting results & Delayed & $63-65$ \\
\hline CX3CR1 & 1249 & No effect & Accelerated & 67 \\
\hline CD4 & C868T & $\begin{array}{c}\text { Augmented, when heterozygously expressed in the } \\
\text { children }\end{array}$ & unknown & 69 \\
\hline DC-SIGN & $p-336 C$ and $p-201 A$ & Augmented, when expressed in the children & unknown & 70 \\
\hline DC-SIGN & $\begin{array}{c}\text { exon } 4 \text { : R198Q, E214D, R221Q, and } \\
\text { L242V }\end{array}$ & Augmented, when expressed in the children & unknown & 70 \\
\hline DC-SIGNR & $\mathrm{H} 1$ and $\mathrm{H} 3$ & Augmented & unknown & 71 \\
\hline CCL3 & Copy number variation & Augmented, when present in the children & unknown & 72 \\
\hline SDF-1 & $3^{\prime} U T R 801 \mathrm{~A}$ & Augmented, when present in the mother & Accelerated & $62,73-76$ \\
\hline
\end{tabular}


reported in this regard. The heterozygous form of this same 32-basepair deletion of the CCR5 gene, when detected in the HIV-1 infected mother does not decrease the risk of transmission [54-61]. It appears, however, to exert a protective effect against MTCT in those children exposed to a low maternal viral burden of an $\mathrm{R} 5$ virus isolate [2].

In sub-Saharan Africa, where MTCT remains an important route of infection but the $\Delta 32$ CCR 5 deletion is rare, Singh et al. recently showed that the single amino acid substitution ( $\mathrm{G}$ to $\mathrm{A}$ or $\mathrm{C}$ to $\mathrm{T}$ ) at position 59029 or 59353 of the CCR 5 promoter is significantly associated with risk of MTCT [62]. The association persists also when adjusted for CD4 counts and antiretroviral treatment of the mother. It is of utmost relevance to notice that the CCR5 mutation 59029 was differently represented in the three cohorts analyzed in this study, being the frequency highest in the South African children compared to the Malawian and Ugandan ones [62]. This underlines the variation depending on ethnicity and the importance of designing studies with appropriate control populations.

Several studies tried to find a correlation of the $\Delta 32$ CCR5 polymorphism with disease progression in infected children. The largest one, an international meta-analysis study, associated this genetic polymorphism with a decreased risk of death among Caucasian perinatally infected children, but only for the first year of life, whereas thereafter the effect was not any longer evident [63].

Chemokine receptors other than CCR5 were studied. A single nucleotide substitution of a valine residue for an isoleucine at position 65 in the CCR2 receptor (CCR2-64I) showed contradicting results when analyzed in relation to MTCT $[64,65]$ but exerted a protective effect on disease progression in perinatally infected children [63]. Structural variants of the chemokine receptor CX3CR1, used by HIV-1 as co-receptor in the central nervous system [66], such as I249 and M280 affecting two amino acids (isoleucine-249 and methionine-280), were associated with rapid progression to AIDS in infected adults. However, in children only the CX3CR1I249 genotype appears to be relevant for fast progression [67]. Furthermore, either these two chemokine receptors, CCR2 and CX3CR1, when studied specifically in sub-Saharan African populations do apparently not have a direct role in MTCT [62]. However, a Nairobi-based study suggests that the maternal CCR2-64I may partially protect against MTCT of HIV-1 by reducing baseline plasma HIV-1 viral load [68]

A polymorphism $(\mathrm{C} 868 \mathrm{~T})$ of the CD4 gene, which is highly prevalent among Africans, plays a significant role in determining a two-fold increase of MTCT when heterozygously expressed in Kenyan children [69]. This same mutation had apparently no effect when expressed in the mother. If the change of the tertiary structure of CD4 induced by this single-nucleotide polymorphism may have a different effect on the association with the co-receptors and thus, selectively influence the binding and entry of R5 viruses compared to $\mathrm{X} 4$ viruses is not known.

DC-specific intracellular adhesion molecule-3-grabbing nonintegrin (DC-SIGN) and DC-SIGNR are C-type lectins that serve as HIV-1 receptor in addition to being cell adhesion and pathogen recognition receptors. DCSIGN is expressed also on placental macrophages. Two promoter variants $(\mathrm{p}-336 \mathrm{C}$ and $\mathrm{p}-201 \mathrm{~A})$ as well as four protein modifying mutations in exon 4 (R198Q, E214D, R221Q, and L242V) of this gene, studied in Zimbabwean children born to HIV-1 positive mothers, are associated with intra partum, in utero and post partum HIV-1 transmission [70]. DC-SIGNR is expressed on the human placenta in the capillary endothelial cells. DCSIGNR single nucleotide polymorphism, $\mathrm{H} 1$ and $\mathrm{H} 3$, studied in a large cohort of children born to HIV-1 infected mothers in Zimbabwe, is associated with increased infection during pregnancy and at birth [71]. Interestingly, this mutation produced lower levels of DC-SIGNR in placental tissue. The Authors speculate that this low production of DC-SIGNR may have implications on alternative infection mechanisms with loss of the protective role of the placental barrier, and possibly favor HIV-1 binding to CCR5, instead of DC-SIGNR, facilitating migration of maternal infected cells across the placental barrier.

The naturally occurring host genetic variants of the chemokine-chemokine receptor axis may have relevance in altering the receptor expression and the host immune response to HIV-1. One possible hypothesis is that the chemokine production of the fetus or child may affect transmission or disease progression. CCL3, 4 and 5 are the natural ligands of CCR5. CCL3 in humans is encoded by two functional genes CCL3 and CCL3-L1; their low copy number in the children but not in the mothers were shown to be associated with transmission of the virus [72]. A particular single nucleotide polymorphism in the CCL3 gene was encountered more frequently in infected children compared to exposed uninfected ones.

The homozygous mutation at position 881 of the 3'untranslated region of the SDF-1 gene (SDF-1 3'A), the ligand for the CXCR4, of the mother but not the infant was associated with MTCT [73]. Another study showed that the protective effect of the heterozygous form of the $\triangle 32$ CCR 5 is restricted by the SDF-1 genotype in HIV-1 infected children [74]. We showed that the presence of the SDF-1 3'A gene correlates with accelerated disease progression in HIV-1- 
infected children born to seropositive mothers but does not protect against MTCT of HIV-1 [75]. These data may indicated that the genetic polymorphism may allow for appearance of CXCR4-using virus variants during disease progression of the children, but that the same mutation does not have any effect on transmission given that most mothers carry CCR5 using viruses.

In studies conducted in Africa the mutated SDF-1 gene instead had no protective effect at all or some effect but only in postpartum transmission $[62,73]$. In addition, in a Kenyan study neither the $\triangle 32$ CCR5 nor the SDF-1 3'A polymorphism were detected in a cohort of HIV-1 infected long term survivor and non-progressor children above 8 years of age [76]. This again underlines the need to identify different prognostic markers according to genetic background.

\section{Cellular targets in different routes of MTCT}

Taken in consideration that transmission from the mother to the child occurs mainly through ingestion of infected fluids in utero, intra partum or via breast milk, or through the placenta it may very well be that HIV-1 utilizes receptor(s) other than CCR5 to infect cells present at the fetus/infant's mucosal sites. Indeed alternative receptors used by HIV-1 were identified on mucosal epithelial cells. Intestinal enterocytes and M-cells were shown to selectively transcytoze virus through binding with galactosyl ceramide (GalCer) [77,78] or Fc receptor [79]. If enterocytes appear to favor in vitro the transport of R5 viral variants, M-cells instead favor X4 viruses. Rescigno et al. demonstrated in vitro and in vivo that DCs can penetrate through tight junctions of the intestinal enterocytes and favor transport of enterobacteria, invasive or not, from the intestinal lumen. Interestingly, CX3CR1 expressed on DCs was shown to be involved in the elongation of the DC's cellular processes [80]. If HIV-1 utilizes a similar mechanism to invade the intestinal mucosa, and if it could select for a particular viral phenotype, remains to be determined.

Tonsils may also be a portal of entry for HIV-1 by ingestion. The tonsils mucosa contains $\mathrm{M}$ cells that lie above regions where DCs are juxtaposed with CD4+ lymphocytes $[81,82]$. In adults oral transmission occurs rarely $[83,84]$ and HIV binding to tonsil epithelium exhibits limited progression to primary infection [85]. In the primate MTCT model, infection was shown to occur through the surface mucosa of the tonsil [86], where transmission of the virus may involve specialized $\mathrm{M}$ cells and DC capable of transporting HIV to the interior of the tonsil. Tonsil lymphoid cells have an increased susceptibility to infection with HIV-1 compared to PBMC, which may in part by ascribed to the increased expression of the viral co-receptor CXCR4 [87].
The other portal of entry specific for in utero MTCT of HIV-1 is the placenta possibly through a transannexial or transplacental passage. HIV-entry into trophoblastic cells has still to be elucidated, as primary trophoblastic cells express CXCR4 and CCR5 but not always CD4 on the surface [12]. HIV-1 was detected mostly in syncytiotrophoblasts, Hofbauer cells and placental macrophages of both early and late placentae [88-93], unless the mother underwent antiretroviral therapy from early on in pregnancy [94]. Trophoblastic cells derived from the outer layer of the healthy placenta or malignant trophoblastic cell lines are permissive to infection by laboratory strains of HIV-1 in vitro [95-97]. In vitro, HIV-1 can transcytose across a trophoblastic barrier or, alternatively, the infected monocytes and lymphocytes can rapidly fuse with trophoblastic cells independently from the viral chemokine-receptor usage [98]. DC-SIGN and ICAM-1 were implied to play a role in the passage of HIV from placental cells to Hofbauer cells or T-lymphocytes $[99,100]$. Furthermore, the maternal deciduals cells are more permissive to infection with R5 than X4 viruses. Moreover, those cells interact directly with the placental cells, which are permissive to cell-to-cell infection, especially during the first trimester of pregnancy. Despite this potential risk, in utero transmission is rare during this period, suggesting that a natural control of the virus may occur [101].

Human term placental cells express the recently discovered second receptor for CXCL12/SDF-1a CXCR7 (RDC1) [102,103], which is known to be a coreceptor for HIV-1, HIV-2 and SIV [104]. Somatic cells expressing CXCR7 show enhanced internalization of the chemokine suggesting that CXCR7 acts as a sink for SDF-1a [105]. If these mechanism may influence a preferential transmission of CCR5 using viruses at placental level remains to be elucidated.

Controversial data were reported regarding the expression levels of CCR5 on placental cells and the risk of vertical transmission. Indeed, up-regulation of CCR5 expression in the placenta was associated with MTCT of HIV-1 [106]. The same study revealed that HIV-1 infects primarily CXCR4-expressing cells in the placenta from non-transmitting women, but predominantly CCR5-expressing cells in those from transmitting women. However, a recent study did not find any correlation between the expression of CCR5 in human placenta and MTCT of HIV-1 in a cohort of mothers from Malawi [107]. Interestingly maternal malaria infection corresponded to a higher expression of CCR5 in the placenta, thus indicating that environmental factor are involved in the regulation of this molecule. In two African studies it was shown that Plasmodium falciparum infection profoundly modifies the placenta cytokine environment [108], and that placental malaria infection 
is associated with an increase in peripheral and placental HIV-1 load [109]. Indeed, the role of malaria infection in favoring MTCT of HIV-1 is still a matter of debate and needs further investigation. According to the latest estimates of WHO/UNAIDS in those areas where malaria is endemic were born the majority of the 430.000 newly HIV-1 infected babies [110].

\section{Conclusion}

As to day viral phenotype was not identified as a predictive marker of MTCT of HIV-1. Genetic polymorphisms are more frequently of relevance in the child than in the mother. Mucosal tissues of the intestine or placenta appear to be involved in the selection of viral phenotypes, due to expression of specific receptors for HIV-1. The driving mechanisms need still further investigation.

The enigma of the R5 phenotype being associated with the state of immune deficiency has been solved with the refined viral characterization, in which viruses are further classified in $\mathrm{R} 5^{\text {broad }}$ or $\mathrm{R} 5^{\text {narrow }}$. Indeed, $\mathrm{R} 5^{\text {broad }}$ viruses have detrimental effect as much as CXCR4-using viruses, and are predictive of fast disease progression in infected children.

\section{Acknowledgements}

The Authors thanks the Istituto Superiore della Sanità, Programma Nazionale AIDS, grant numbers 40G.56 and 45G.36, EUROPRISE, EC grant LSHP-CT-2006037611, and the European Community's Seventh Framework Programme (FP7/2007-2013) under grant agreement n 201433 (NGIN), for their financial support.

This article has been published as part of Journal of Translational Medicine Volume 9 Supplement 1, 2011: Differential use of CCR5 vs. CSCR4 by HIV-1. Pathogenic, Translational and Clinical Open Questions. The full contents of the supplement are available online at http://www.translational-medicine. com/supplements/9/S1.

\section{Competing interests}

The authors declare that no competing interests exist.

Published: 27 January 2011

\section{References}

1. Casper CH, Clevestig P, Carlenor E, Leitner T, Anzen B, Lidman K, Belfrage E, Albert J, Bohlin AB, Naver $L$, et al: Link between the $X 4$ phenotype in human immunodeficiency virus type 1-infected mothers and their children, despite the early presence of R5 in the child. J Infect Dis 2002, 186:914-921

2. Ometto L, Zanchetta M, Mainardi M, De Salvo GL, Garcia-Rodriguez MC, Gray L, Newell ML, Chieco-Bianchi L, De Rossi A: Co-receptor usage of HIV1 primary isolates, viral burden, and CCR5 genotype in mother-to-child HIV-1 transmission. AIDS 2000, 14:1721-1729.

3. Ometto L, Zanotto C, Maccabruni A, Caselli D, Truscia D, Giaquinto C, Ruga E, Chieco-Bianchi L, De Rossi A: Viral phenotype and host-cell susceptibility to HIV-1 infection as risk factors for mother-to-child HIV-1 transmission. AIDS 1995, 9:427-434.

4. Salvatori F, Scarlatti G: HIV type 1 chemokine receptor usage in mother-to-child transmission. AIDS Res Hum Retroviruses 2001, 17:925-935

5. Karlsson I, Antonsson L, Shi Y, Oberg M, Karlsson A, Albert J, Olde B, Owman C, Jansson M, Fenyo EM: Coevolution of RANTES sensitivity and mode of CCR5 receptor use by human immunodeficiency virus type 1 of the R5 phenotype. J Virol 2004, 78:11807-11815.
6. Cavarelli M, Karlsson I, Zanchetta M, Antonsson L, Plebani A, Giaquinto C, Fenyo EM, De Rossi A, Scarlatti G: HIV-1 with multiple CCR5/CXCR4 chimeric receptor use is predictive of immunological failure in infected children. PLOS ONE 2008, 3:e3292.

7. Scarlatti G, Hodara V, Rossi P, Muggiasca L, Bucceri A, Albert J, Fenyo EM: Transmission of human immunodeficiency virus type 1 (HIV-1) from mother to child correlates with viral phenotype. Virology 1993, 197:624-629.

8. Hemelaar J, Gouws E, Ghys PD, Osmanov S: Global and regional distribution of HIV-1 genetic subtypes and recombinants in 2004. AIDS 2006, 20:W13-23.

9. Choge I, Cilliers T, Walker P, Taylor N, Phoswa M, Meyers T, Viljoen J, Violari A, Gray G, Moore PL, et al: Genotypic and phenotypic characterization of viral isolates from HIV-1 subtype C-infected children with slow and rapid disease progression. AIDS Res Hum Retroviruses 2006 22:458-465.

10. Zhang H, Hoffmann F, He J, He X, Kankasa C, Ruprecht R, West JT, Orti G, Wood C: Evolution of subtype C HIV-1 Env in a slowly progressing Zambian infant. Retrovirology 2005, 2:67.

11. Tscherning-Casper C, Vodros D, Menu E, Aperia K, Fredriksson R, Dolcini G, Chaouat G, Barre-Sinoussi F, Albert J, Fenyo EM: Coreceptor usage of HIV-1 isolates representing different genetic subtypes obtained from pregnant Cameroonian women. European Network for In Utero Transmission of HIV-1. J Acquir Immune Defic Syndr 2000, 24:1-9.

12. Mognetti B, Moussa M, Croitoru J, Menu E, Dormont D, Roques $P$, Chaouat G: HIV-1 co-receptor expression on trophoblastic cells from early placentas and permissivity to infection by several HIV-1 primary isolates. Clin Exp Immunol 2000, 119:486-492.

13. Wolinsky SM, Wike CM, Korber BT, Hutto C, Parks WP, Rosenblum LL, Kunstman KJ, Furtado MR, Munoz JL: Selective transmission of human immunodeficiency virus type-1 variants from mothers to infants. Science 1992, 255:1134-1137.

14. Dickover RE, Garratty EM, Plaeger S, Bryson YJ: Perinatal transmission of major, minor, and multiple maternal human immunodeficiency virus type 1 variants in utero and intrapartum. J Virol 2001, 75:2194-2203.

15. Kwiek JJ, Russell ES, Dang KK, Burch CL, Mwapasa V, Meshnick SR, Swanstrom R: The molecular epidemiology of HIV-1 envelope diversity during HIV-1 subtype $C$ vertical transmission in Malawian mother-infant pairs. AIDS 2008, 22:863-871.

16. Scarlatti G, Albert J, Rossi P, Hodara V, Biraghi P, Muggiasca L, Fenyo EM: Mother-to-child transmission of human immunodeficiency virus type 1: correlation with neutralizing antibodies against primary isolates. $J$ Infect Dis 1993, 168:207-210.

17. Scarlatti $G$, Lombardi V, Plebani A, Principi N, Vegni C, Ferraris G, Bucceri A, Fenyo EM, Wigzell $H$, Rossi $P$, et al: Polymerase chain reaction, virus isolation and antigen assay in HIV-1-antibody-positive mothers and their children. AIDS 1991, 5:1173-1178.

18. Wike CM, Korber BT, Daniels MR, Hutto C, Munoz J, Furtado M, Parks W, Saah A, Bulterys M, Kurawige JB, et al: HIV-1 sequence variation between isolates from mother-infant transmission pairs. AIDS Res Hum Retroviruses 1992, 8:1297-1300.

19. Renjifo B, Gilbert P, Chaplin B, Msamanga G, Mwakagile D, Fawzi W, Essex M: Preferential in-utero transmission of HIV-1 subtype C as compared to HIV-1 subtype A or D. AIDS 2004, 18:1629-1636.

20. De Rossi A, Masiero S, Giaquinto C, Ruga E, Comar M, Giacca M, ChiecoBianchi L: Dynamics of viral replication in infants with vertically acquired human immunodeficiency virus type 1 infection. J Clin Invest 1996, 97:323-330.

21. Lathey JL, Tsou J, Brinker K, Hsia K, Meyer WA 3rd, Spector SA: Lack of autologous neutralizing antibody to human immunodeficiency virus type 1 (HIV-1) and macrophage tropism are associated with mother-toinfant transmission. J Infect Dis 1999, 180:344-350.

22. Ayyavoo V, Ugen KE, Fernandes LS, Goedert JJ, Rubinstein A, Williams WW, Weiner DB: Analysis of genetic heterogeneity, antigenicity, and biological characteristics of HIV-1 in a maternal transmitter and nontransmitter patient pair. DNA Cell Biol 1996, 15:571-580.

23. Huang W, Eshleman SH, Toma J, Stawiski E, Whitcomb JM, Jackson JB, Guay L, Musoke P, Parkin N, Petropoulos CJ: Vertical transmission of X4tropic and dual-tropic HIV-1 in five Ugandan mother-infant pairs. Aids 2009, 23:1903-1908. 
24. Clevestig P, Maljkovic I, Casper C, Carlenor E, Lindgren S, Naver L, Bohlin AB, Fenyo EM, Leitner T, Ehrnst A: The X4 phenotype of HIV type 1 evolves from R5 in two children of mothers, carrying $\mathrm{X} 4$, and is not linked to transmission. AIDS Res Hum Retroviruses 2005, 21:371-378.

25. Auger I, Thomas P, De Gruttola V, Morse D, Moore D, Williams R, Truman B, Lawrence CE: Incubation periods for paediatric AIDS patients. Nature 1988, 336:575-577.

26. Blanche S, Rouzioux C, Moscato ML, Veber F, Mayaux MJ, Jacomet C, Tricoire J, Deville A, Vial M, Firtion G, et al: A prospective study of infants born to women seropositive for human immunodeficiency virus type 1 . HIV Infection in Newborns French Collaborative Study Group. N Engl J Med 1989, 320:1643-1648.

27. Balotta C, Colombo MC, Colucci G, Vigano A, Riva C, Papagno L, Violin M, Crupi L, Bricalli D, Salvaggio A, et al: Plasma viremia and virus phenotype are correlates of disease progression in vertically human immunodeficiency virus type 1-infected children. Pediatr Infect Dis J 1997, 16:205-211.

28. Balotta C, Vigano A, Riva C, Colombo MC, Salvaggio A, de Pasquale MP, Crupi L, Papagno L, Galli M, Moroni M, Principi N: HIV type 1 phenotype correlates with the stage of infection in vertically infected children. AIDS Res Hum Retroviruses 1996, 12:1247-1253.

29. Resino S, Gurbindo D, Cano JM, Sanchez-Ramon S, Muoz-Fernandez MA: Predictive markers of clinical outcome in vertically HIV-1-infected infants. A prospective longitudinal study. Pediatr Res 2000, 47:509-515.

30. Strunnikova N, Ray SC, Livingston RA, Rubalcaba E, Viscidi RP: Convergent evolution within the V3 loop domain of human immunodeficiency virus type 1 in association with disease progression. J Virol 1995, 69:7548-7558.

31. Hutto C, Zhou Y, He J, Geffin R, Hill M, Scott W, Wood C: Longitudinal studies of viral sequence, viral phenotype, and immunologic parameters of human immunodeficiency virus type 1 infection in perinatally infected twins with discordant disease courses. J Virol 1996, 70:3589-3598.

32. Scarlatti G, Tresoldi E, Bjorndal A, Fredriksson R, Colognesi C, Deng HK, Malnati MS, Plebani A, Siccardi AG, Littman DR, et al: In vivo evolution of HIV-1 co-receptor usage and sensitivity to chemokine-mediated suppression. Nat Med 1997, 3:1259-1265.

33. Fitzgibbon JE, Gaur S, Gavai M, Gregory P, Frenkel LD, John JF Jr.: Effect of the HIV-1 syncytium-inducing phenotype on disease stage in verticallyinfected children. J Med Virol 1998, 55:56-63.

34. Gupta P, Urbach A, Cosentino L, Thampatty P, Brady M: HIV-1 isolates from children with or without AIDS have similar in vitro biologic properties. Aids 1993, 7:1561-1564.

35. Kopka J, Batalla M, Mangano A, Mecikovsky D, Bologna R, Sen L: Relevance of viral phenotype in the early AIDS outcome of pediatric HIV-1 primary infection. Pediatr Res 2002, 52:475-480.

36. Daar ES, Kesler KL, Petropoulos CJ, Huang W, Bates M, Lail AE, Coakley EP, Gomperts ED, Donfield SM: Baseline HIV type 1 coreceptor tropism predicts disease progression. Clin Infect Dis 2007, 45:643-649.

37. Ripamonti C, Leitner T, Lauren A, Karlsson I, Pastore A, Cavarelli M, Antonsson L, Plebani A, Fenyo EM, Scarlatti G: Biological and genetic evolution of HIV type 1 in two siblings with different patterns of disease progression. AIDS Res Hum Retroviruses 2007, 23:1531-1540.

38. Garzino-Demo A, Moss RB, Margolick JB, Cleghorn F, Sill A, Blattner WA, Cocchi F, Carlo DJ, DeVico AL, Gallo RC: Spontaneous and antigeninduced production of HIV-inhibitory beta-chemokines are associated with AIDS-free status. Proc Natl Acad Sci U S A 1999, 96:1 1986-11991.

39. Ullum H, Cozzi Lepri A, Victor J, Aladdin H, Phillips AN, Gerstoft J, Skinhoj P, Pedersen BK: Production of beta-chemokines in human immunodeficiency virus (HIV) infection: evidence that high levels of macrophage inflammatory protein-1 beta are associated with a decreased risk of HIV disease progression. J Infect Dis 1998, 177:331-336.

40. Tuttle DL, Coberley CR, Xie X, Kou ZC, Sleasman JW, Goodenow MM: Effects of human immunodeficiency virus type 1 infection on CCR5 and CXCR4 coreceptor expression on CD4 T lymphocyte subsets in infants and adolescents. AIDS Res Hum Retroviruses 2004, 20:305-313.

41. Bleul CC, Wu L, Hoxie JA, Springer TA, Mackay CR: The HIV coreceptors CXCR4 and CCR5 are differentially expressed and regulated on human T lymphocytes. Proc Natl Acad Sci U S A 1997, 94:1925-1930.

42. Mo H, Monard S, Pollack H, Ip J, Rochford G, Wu L, Hoxie J, Borkowsky W, Ho DD, Moore JP: Expression patterns of the HIV type 1 coreceptors CCR5 and CXCR4 on CD4+ T cells and monocytes from cord and adult blood. AIDS Res Hum Retroviruses 1998, 14:607-617.
43. Sleasman JW, Aleixo LF, Morton A, Skoda-Smith S, Goodenow MM: CD4+ memory $\mathrm{T}$ cells are the predominant population of HIV-1-infected lymphocytes in neonates and children. Aids 1996, 10:1477-1484.

44. Blaak $H$, van't Wout $A B$, Brouwer M, Hooibrink B, Hovenkamp E, Schuitemaker $\mathrm{H}$ : In vivo HIV-1 infection of CD45RA(+)CD4(+) T cells is established primarily by syncytium-inducing variants and correlates with the rate of CD4(+) T cell decline. Proc Natl Acad Sci U S A 2000, 97:1269-1274.

45. Zaitseva MB, Lee S, Rabin RL, Tiffany HL, Farber JM, Peden KW, Murphy PM, Golding H: CXCR4 and CCR5 on human thymocytes: biological function and role in HIV-1 infection. J Immunol 1998, 161:3103-3113.

46. Ho WZ, Lioy J, Song L, Cutilli JR, Polin RA, Douglas SD: Infection of cord blood monocyte-derived macrophages with human immunodeficiency virus type 1. J Virol 1992, 66:573-579.

47. Geijtenbeek TB, Kwon DS, Torensma R, van Vliet SJ, van Duijnhoven GC, Middel J, Cornelissen IL, Nottet HS, KewalRamani VN, Littman DR, et al: DCSIGN, a dendritic cell-specific HIV-1-binding protein that enhances transinfection of T cells. Cell 2000, 100:587-597.

48. Liu R, Paxton WA, Choe S, Ceradini D, Martin SR, Horuk R, MacDonald ME, Stuhlmann H, Koup RA, Landau NR: Homozygous defect in HIV-1 coreceptor accounts for resistance of some multiply-exposed individuals to HIV-1 infection. Cell 1996, 86:367-377.

49. Martin MP, Dean M, Smith MW, Winkler C, Gerrard B, Michael NL, Lee B, Doms RW, Margolick J, Buchbinder S, et al: Genetic acceleration of AIDS progression by a promoter variant of CCR5. Science 1998, 282:1907-1911.

50. Rana S, Besson G, Cook DG, Rucker J, Smyth RJ, Yi Y, Turner JD, Guo HH, Du JG, Peiper SC, et al: Role of CCR5 in infection of primary macrophages and lymphocytes by macrophage-tropic strains of human immunodeficiency virus: resistance to patient-derived and prototype isolates resulting from the delta ccr5 mutation. J Virol 1997, 71:3219-3227.

51. Wu L, Paxton WA, Kassam N, Ruffing N, Rottman JB, Sullivan N, Choe H, Sodroski J, Newman W, Koup RA, Mackay CR: CCR5 levels and expression pattern correlate with infectability by macrophage-tropic HIV-1, in vitro. J Exp Med 1997, 185:1681-1691.

52. Samson M, Labbe O, Mollereau C, Vassart G, Parmentier M: Molecular cloning and functional expression of a new human CC-chemokine receptor gene. Biochemistry 1996, 35:3362-3367.

53. Philpott S, Burger H, Charbonneau T, Grimson R, Vermund SH, Visosky A, Nachman S, Kovacs A, Tropper P, Frey H, Weiser B: CCR5 genotype and resistance to vertical transmission of HIV-1. J Acquir Immune Defic Syndr 1999, 21:189-193.

54. Edelstein RE, Arcuino LA, Hughes JP, Melvin AJ, Mohan KM, King PD, McLellan CL, Murante BL, Kassman BP, Frenkel LM: Risk of mother-to-infant transmission of HIV-1 is not reduced in CCR5/delta32ccr5 heterozygotes. J Acquir Immune Defic Syndr Hum Retrovirol 1997, 16:243-246.

55. Hoffman TL, MacGregor RR, Burger H, Mick R, Doms RW, Collman RG: CCR5 genotypes in sexually active couples discordant for human immunodeficiency virus type 1 infection status. J Infect Dis 1997, 176:1093-1096

56. Mandl CW, Aberle SW, Henkel JH, Puchhammer-Stockl E, Heinz FX: Possible influence of the mutant CCR5 Allele on vertical transmission of HIV-1. Med Virol 1998, 55:51-55.

57. Mangano A, Prada F, Roldan A, Picchio G, Bologna R, Sen L: Distribution of CCR-5 delta32 allele in Argentinian children at risk of HIV-1 infection: its role in vertical transmission. AIDS 1998, 12:109-110.

58. Misrahi M, Teglas JP, N'Go N, Burgard M, Mayaux MJ, Rouzioux C Delfraissy JF, Blanche S: CCR5 chemokine receptor variant in HIV-1 mother-to-child transmission and disease progression in children. French Pediatric HIV Infection Study Group. JAMA 1998, 279:277-280.

59. Romiti ML, Colognesi C, Cancrini C, Mas A, Berrino M, Salvatori F, Orlandi P, Jansson M, Palomba E, Plebani A, et al: Prognostic value of a CCR5 defective allele in pediatric HIV-1 infection. Mol Med 2000, 6:28-36.

60. Rousseau CM, Just JJ, Abrams EJ, Casabona J, Stein Z, King MC: CCR5del32 in perinatal HIV-1 infection. J Acquir Immune Defic Syndr Hum Retrovirol 1997, 16:239-242.

61. Shearer WT, Kalish LA, Zimmerman PA: CCR5 HIV-1 vertical transmission. Women and Infants Transmission Study Group. J Acquir Immune Defic Syndr Hum Retrovirol 1998, 17:180-181.

62. Singh KK, Hughes MD, Chen J, Phiri K, Rousseau C, Kuhn L, Coutsoudis A, Jackson JB, Guay LA, Musoke P, et al: Associations of chemokine receptor polymorphisms With HIV-1 mother-to-child transmission in sub-Saharan 
Africa: possible modulation of genetic effects by antiretrovirals. J Acquir Immune Defic Syndr 2008, 49:259-265.

63. Ioannidis JP, Contopoulos-loannidis DG, Rosenberg PS, Goedert JJ, De Rossi A, Espanol T, Frenkel L, Mayaux MJ, Newell ML, Pahwa SG, et al: Effects of CCR5-delta32 and CCR2-64I alleles on disease progression of perinatally HIV-1-infected children: an international meta-analysis. AIDS 2003, 17:1631-1638.

64. Mangano A, Kopka J, Batalla M, Bologna R, Sen L: Protective effect of CCR2-64I and not of CCR5-delta32 and SDF1-3'A in pediatric HIV-1 infection. J Acquir Immune Defic Syndr 2000, 23:52-57.

65. Teglas JP, N'Go N, Burgard M, Mayaux MJ, Rouzioux C, Blanche $S$, Delfraissy JF, Misrahi M: CCR2B-64I chemokine receptor allele and mother-to-child HIV-1 transmission or disease progression in children French pediatric HIV infection study group. J Acquir Immune Defic Syndr 1999, 22:267-271.

66. Faure S, Meyer L, Costagliola D, Vaneensberghe C, Genin E, Autran B, Delfraissy JF, McDermott DH, Murphy PM, Debre P, et al: Rapid progression to AIDS in HIV+ individuals with a structural variant of the chemokine receptor CX3CR1. Science 2000, 287:2274-2277.

67. Singh KK, Hughes MD, Chen J, Spector SA: Genetic polymorphisms in CX3CR1 predict HIV-1 disease progression in children independently of CD4+ lymphocyte count and HIV-1 RNA load. J Infect Dis 2005, 191:1971-1980.

68. Mabuka JM, Mackelprang RD, Lohman-Payne B, Majiwa M, Bosire R, JohnStewart G, Rowland-Jones S, Overbaugh J, Farquhar C: CCR2-64I polymorphism is associated with lower maternal HIV-1 viral load and reduced vertical HIV-1 transmission. J Acquir Immune Defic Syndr 2009, 51:235-237.

69. Choi RY, Farquhar C, Juno J, Mbori-Ngacha D, Lohman-Payne B, Vouriot F, Wayne S, Tuff J, Bosire R, John-Stewart G, Fowke K: Infant CD4 C868T polymorphism is associated with increased human immunodeficiency virus (HIV-1) acquisition. Clin Exp Immunol 2010, 160:461-465.

70. Boily-Larouche G: DC-SIGN variants are associated with mother to child transmission of HIV-1. In Proceedings of the XVIII International AIDS Conference; July, 18-23, Vienna, Austria. International AIDS Society 2010, FRAA0105.

71. Boily-Larouche G, Iscache AL, Zijenah LS, Humphrey JH, Mouland AJ, Ward BJ, Roger M: Functional genetic variants in DC-SIGNR are associated with mother-to-child transmission of HIV-1. PLoS One 2009, 4 e7211.

72. Meddows-Taylor S, Donninger SL, Paximadis M, Schramm DB, Anthony FS, Gray GE, Kuhn L, Tiemessen CT: Reduced ability of newborns to produce CCL3 is associated with increased susceptibility to perinatal human immunodeficiency virus 1 transmission. J Gen Virol 2006, 87:2055-2065.

73. John GC, Rousseau C, Dong T, Rowland-Jones S, Nduati R, Mbori-Ngacha D, Rostron T, Kreiss JK, Richardson BA, Overbaugh J: Maternal SDF1 3'A polymorphism is associated with increased perinatal human immunodeficiency virus type 1 transmission. J Virol 2000, 74:5736-5739.

74. Sei S, Boler AM, Nguyen GT, Stewart SK, Yang QE, Edgerly M, Wood LV, Brouwers P, Venzon DJ: Protective effect of CCR5 delta 32 heterozygosity is restricted by SDF-1 genotype in children with HIV-1 infection. AIDS 2001, 15:1343-1352.

75. Tresoldi E, Romiti ML, Boniotto M, Crovella S, Salvatori F, Palomba E, Pastore A, Cancrini C, de Martino M, Plebani A, et al: Prognostic value of the stromal cell-derived factor $13^{\prime} \mathrm{A}$ mutation in pediatric human immunodeficiency virus type 1 infection. J Infect Dis 2002, 185:696-700.

76. Chakraborty R, Morel AS, Sutton JK, Appay V, Ripley RM, Dong T, Rostron T, Ogola S, Palakudy T, Musoke R, et al: Correlates of delayed disease progression in HIV-1-infected Kenyan children. J Immunol 2005, 174:8191-8199

77. Bomsel M: Transcytosis of infectious human immunodeficiency virus across a tight human epithelial cell line barrier. Nat Med 1997, 3:42-47

78. Fotopoulos G, Harari A, Michetti P, Trono D, Pantaleo G, Kraehenbuhl JP: Transepithelial transport of HIV-1 by M cells is receptor-mediated. Proc Natl Acad Sci U S A 2002, 99:9410-9414.

79. Schneider $T$, Ullrich R, Zeitz $M$ : The immunologic aspects of human immunodeficiency virus infection in the gastrointestinal tract. Semin Gastrointest Dis 1996, 7:19-29.

80. Niess JH, Brand S, Gu X, Landsman L, Jung S, McCormick BA, Vyas JM, Boes M, Ploegh HL, Fox JG, et al: CX3CR1-mediated dendritic cell access to the intestinal lumen and bacterial clearance. Science 2005, 307:254-258.
81. Frankel SS, Tenner-Racz K, Racz P, Wenig BM, Hansen CH, Heffner D, Nelson AM, Pope M, Steinman RM: Active replication of HIV-1 at the lymphoepithelial surface of the tonsil. Am J Pathol 1997, 151:89-96.

82. Frankel SS, Wenig BM, Burke AP, Mannan P, Thompson LD, Abbondanzo SL, Nelson AM, Pope M, Steinman RM: Replication of HIV-1 in dendritic cellderived syncytia at the mucosal surface of the adenoid. Science 1996, 272:115-117.

83. Gilbart VL, Evans BG, Dougan S: HIV transmission among men who have sex with men through oral sex. Sex Transm Infect 2004, 80:324.

84. Page-Shafer K, Shiboski CH, Osmond DH, Dilley J, McFarland W, Shiboski SC, Klausner JD, Balls J, Greenspan D, Greenspan JS: Risk of HIV infection attributable to oral sex among men who have sex with men and in the population of men who have sex with men. Aids 2002, 16:2350-2352.

85. Maher D, Wu X, Schacker T, Larson M, Southern P: A model system of oral HIV exposure, using human palatine tonsil, reveals extensive binding of HIV infectivity, with limited progression to primary infection. J Infect Dis 2004, 190:1989-1997.

86. Stahl-Hennig C, Steinman RM, Tenner-Racz K, Pope M, Stolte N, MatzRensing K, Grobschupff G, Raschdorff B, Hunsmann G, Racz P: Rapid infection of oral mucosal-associated lymphoid tissue with simian immunodeficiency virus. Science 1999, 285:1261-1265.

87. Moutsopoulos NM, Vazquez N, Greenwell-Wild T, Ecevit I, Horn J, Orenstein J, Wahl SM: Regulation of the tonsil cytokine milieu favors HIV susceptibility. J Leukoc Biol 2006, 80:1145-1155.

88. Amirhessami-Aghili N, Spector SA: Human immunodeficiency virus type infection of human placenta: potential route for fetal infection. $J$ Virol 1991, 65:2231-2236

89. Backe $\mathrm{E}$, Jimenez $\mathrm{E}$, Unger $\mathrm{M}$, Schafer $\mathrm{A}$, Jauniaux $\mathrm{E}$, Vogel $\mathrm{M}$ : Demonstration of HIV-1 infected cells in human placenta by in situ hybridisation and immunostaining. J Clin Pathol 1992, 45:871-874.

90. Chandwani S, Greco MA, Mittal K, Antoine C, Krasinski K, Borkowsky W: Pathology and human immunodeficiency virus expression in placentas of seropositive women. J Infect Dis 1991, 163:1134-1138.

91. Lewis SH, Reynolds-Kohler C, Fox HE, Nelson JA: HIV-1 in trophoblastic and villous Hofbauer cells, and haematological precursors in eight-week fetuses. Lancet 1990, 335:565-568.

92. Martin AW, Brady K, Smith SI, DeCoste D, Page DV, Malpica A, Wolf B, Neiman RS: Immunohistochemical localization of human immunodeficiency virus p24 antigen in placental tissue. Hum Pathol 1992, 23:411-414.

93. Menu E, Mbopi-Keou FX, Lagaye S, Pissard S, Mauclere P, Scarlatti G, Martin J, Goossens M, Chaouat G, Barre-Sinoussi F: Selection of maternal human immunodeficiency virus type 1 variants in human placenta. European Network for In Utero Transmission of HIV-1. J Infect Dis 1999, 179:44-51

94. Tscherning-Casper C, Papadogiannakis N, Anvret M, Stolpe L, Lindgren S, Bohlin AB, Albert J, Fenyo EM: The trophoblastic epithelial barrier is not infected in full-term placentae of human immunodeficiency virusseropositive mothers undergoing antiretroviral therapy. J Virol 1999, 73:9673-9678.

95. David FJ, Autran B, Tran HC, Menu E, Raphael M, Debre P, Hsi BL, Wegman TG, Barre-Sinoussi F, Chaouat G: Human trophoblast cells express CD4 and are permissive for productive infection with HIV-1. Clin Exp Immunol 1992, 88:10-16.

96. David FJ, Tran HC, Serpente N, Autran B, Vaquero C, Djian V, Menu E, BarreSinoussi F, Chaouat G: HIV infection of choriocarcinoma cell lines derived from human placenta: the role of membrane CD4 and Fc-Rs into HIV entry. Virology 1995, 208:784-788.

97. Mano H, Chermann JC: Replication of human immunodeficiency virus type 1 in primary cultured placental cells. Res Virol 1991, 142:95-104.

98. Lagaye S, Derrien M, Menu E, Coito C, Tresoldi E, Mauclere P, Scarlatti G, Chaouat G, Barre-Sinoussi F, Bomsel M: Cell-to-cell contact results in a selective translocation of maternal human immunodeficiency virus type 1 quasispecies across a trophoblastic barrier by both transcytosis and infection. J Virol 2001, 75:4780-4791.

99. Arias RA, Munoz LD, Munoz-Fernandez MA: Transmission of HIV-1 infection between trophoblast placental cells and T-cells take place via an LFA-1-mediated cell to cell contact. Virology 2003, 307:266-277.

100. Geijtenbeek TB, van Vliet SJ, van Duijnhoven GC, Figdor CG, van Kooyk Y: DC-SIGN, a dentritic cell-specific HIV-1 receptor present in placenta that infects T cells in trans-a review. Placenta 2001, 22(Suppl A):S19-23. 
101. Marlin R, Nugeyre MT, de Truchis C, Berkane N, Gervaise A, Barre-Sinoussi F, Menu E: Antigen-presenting cells represent targets for R5 HIV-1 infection in the first trimester pregnancy uterine mucosa. PLoS One 2009, 4:e5971.

102. Balabanian K, Lagane B, Infantino S, Chow KY, Harriague J, Moepps B, Arenzana-Seisdedos F, Thelen M, Bachelerie F: The chemokine SDF-1/ CXCL12 binds to and signals through the orphan receptor RDC1 in T lymphocytes. J Biol Chem 2005, 280:35760-35766.

103. Tripathi V, Verma R, Dinda A, Malhotra N, Kaur J, Luthra K: Differential expression of RDC1/CXCR7 in the human placenta. J Clin Immunol 2009, 29:379-386.

104. Shimizu N, Soda Y, Kanbe K, Liu HY, Mukai R, Kitamura T, Hoshino H: A putative $\mathrm{G}$ protein-coupled receptor, $\mathrm{RDC1}$, is a novel coreceptor for human and simian immunodeficiency viruses. J Virol 2000, 74:619-626.

105. Boldajipour B, Mahabaleshwar H, Kardash E, Reichman-Fried M, Blaser H, Minina S, Wilson D, Xu Q, Raz E: Control of chemokine-guided cell migration by ligand sequestration. Cell 2008, 132:463-473.

106. Behbahani H, Popek E, Garcia P, Andersson J, Spetz AL, Landay A, Flener Z, Patterson BK: Up-regulation of CCR5 expression in the placenta is associated with human immunodeficiency virus-1 vertical transmission. Am J Pathol 2000, 157:1811-1818.

107. Joubert BR, Franceschini N, Mwapasa V, North KE, Meshnick SR: Regulation of CCR5 expression in human placenta: insights from a study of motherto-child transmission of HIV in Malawi. PLoS On 2010, 5:e9212.

108. Kfutwah A, Mary JY, Lemen B, Leke R, Rousset D, Barre-Sinoussi F, Nerrienet $E$, Menu $E$, Ayouba A: Plasmodium falciparum infection significantly impairs placental cytokine profile in HIV infected Cameroonian women. PLoS One 2009, 4:e8114.

109. Mwapasa V, Rogerson SJ, Molyneux ME, Abrams ET, Kamwendo DD, Lema VM, Tadesse E, Chaluluka E, Wilson PE, Meshnick SR: The effect of Plasmodium falciparum malaria on peripheral and placental HIV-1 RNA concentrations in pregnant Malawian women. AIDS 2004, 18:1051-1059.

110. [http://www.unaids.org/en/KnowledgeCentre/HIVData/GlobalReport/ 2008], posting date. [Online.].

111. Center for Disease Control: 1994 Revised classification system for human immunodeficiency virus infection in children less than 13 years of age. Morbid Mortal Wkly Rep 1994, 43:1-10.

doi:10.1186/1479-5876-9-S1-S10

Cite this article as: Cavarelli and Scarlatti: HIV-1 co-receptor usage: influence on mother-to-child transmission and pediatric infection. Journal of Translational Medicine 2010 9(Suppl 1):S10.

\section{Submit your next manuscript to BioMed Central and take full advantage of:}

- Convenient online submission

- Thorough peer review

- No space constraints or color figure charges

- Immediate publication on acceptance

- Inclusion in PubMed, CAS, Scopus and Google Scholar

- Research which is freely available for redistribution

Submit your manuscript at www.biomedcentral.com/submit
Biomed Central 